\title{
CHAPTER B: METAMORPHISM OF THE LADUE RIVER-MOUNT FAIRPLAY AREA
}

\author{
R.J. Newberry ${ }^{1}$ and Evan Twelker ${ }^{2}$
}

\section{INTRODUCTION}

The metamorphic rocks of the Ladue RiverMount Fairplay study area comprise several assemblages or groups of units (fig. 1) that can be distinguished based on differences in their peak metamorphic grade. These include: greenschistfacies ultramafic rocks and the rocks assigned to the Klondike assemblage; lower amphibolitefacies rocks of the Ladue River unit; and upper amphibolite-facies rocks of the Lake George assemblage and Jarvis belt. The spatial distribution of these metamorphic grade differences corresponds to the patterns observed for ${ }^{40} \mathrm{Ar} /{ }^{39} \mathrm{Ar}$ metamorphic cooling ages: the rocks of the allochthonous YukonTanana terrane (YTT; Klondike and Fortymile River, Snowcap assemblages, Ladue River unit) cooled prior to the Cretaceous (Permian through Jurassic), and rocks of parautochthonous North America (pNA; Lake George assemblage) cooled during the Early Cretaceous (Pavlis and others, 1993; Dusel-Bacon and others, 2002; Naibert and others, 2020; Jones and Benowitz, 2020).

Legend
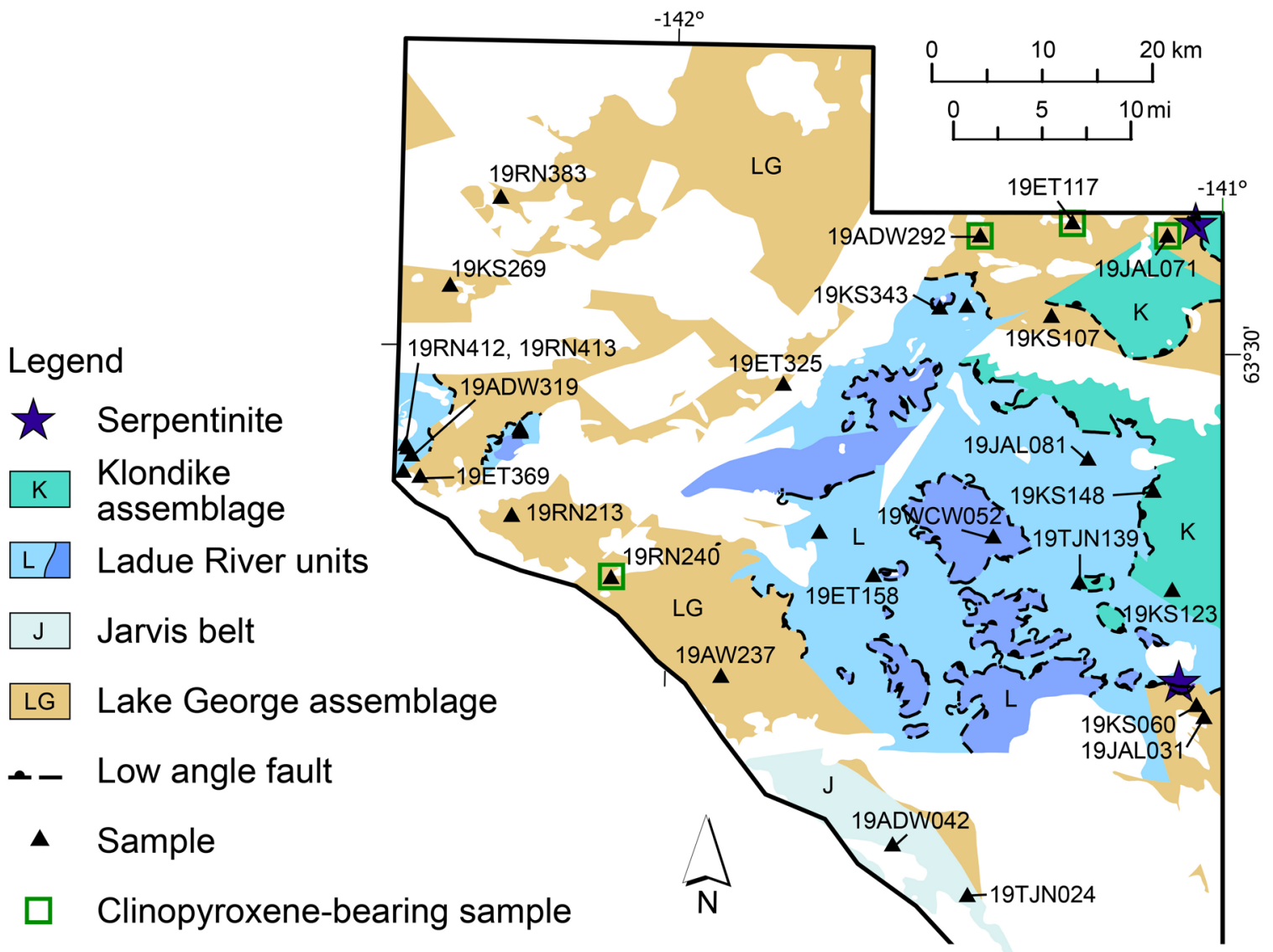

Figure 1. Map illustrating the major metamorphic assemblages of the map area and the locations of microprobeanalyzed samples.

${ }^{1}$ Department of Geosciences, University of Alaska, P.O. Box 755780, Fairbanks, Alaska 99775-5780

${ }^{2}$ Alaska Division of Geological \& Geophysical Surveys, 3354 College Rd., Fairbanks, Alaska 99709-3707 
Rocks with older metamorphic cooling ages record a metamorphic event that is older and separate from that observed in the Lake George assemblage, probably the Middle Permian-Early Triassic Klondike orogeny documented only in the allochthonous terranes (Beranek and Mortensen, 2011; van Staal and others, 2018). The higher-grade metamorphism with Early Cretaceous cooling ages reflects a later, separate event most likely related to the emplacement of the YTT over pNA, combined with the thermal effects of widespread mid-Cretaceous plutonism. The juxtaposition of older cooling ages on top of younger cooling ages indicates missing 'thermal section' and is evidence of low-angle, extensional motion on faults that separate the YTT and pNA (Pavlis and others, 1993, Hansen and Dusel-Bacon, 1998).

The purpose of this chapter is to describe the metamorphism of each map unit, specifically as it relates to the practical exercise of identifying and mapping the fundamental metamorphic assemblages in the study area. We have used thin section petrography supported by electron probe microanalyses, energy dispersive spectroscopy to identify minerals and track the compositional variations of plagioclase and hornblende, which vary with metamorphic grade. Establishing the chronology and

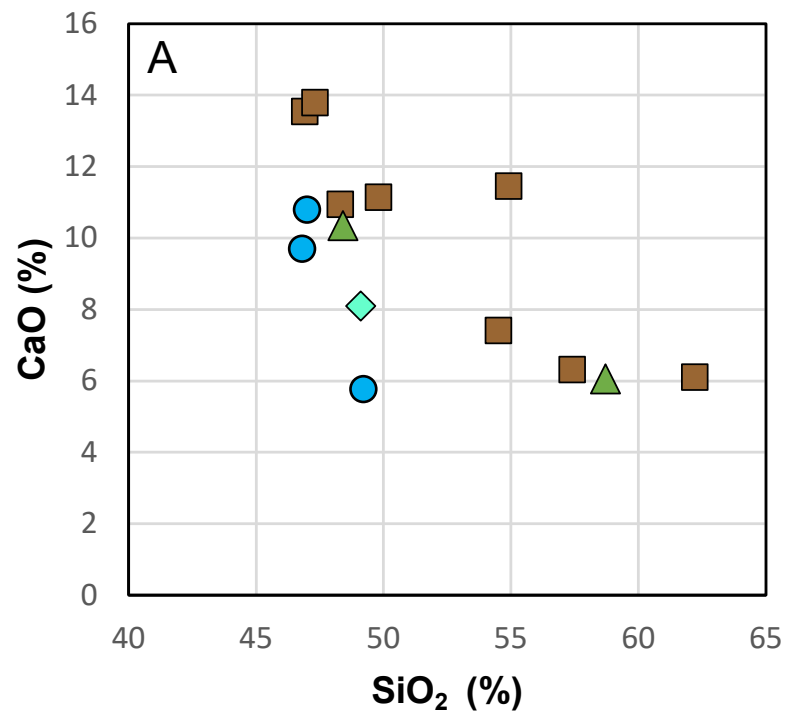

the pressure-temperature conditions of metamorphism are beyond the scope of this chapter.

\section{ANALYTICAL METHODS}

We selected metamorphic rocks of mafic composition (amphibolite, greenstone) for petrographic and electron probe microanalysis because these rocks contain metamorphic-facies-diagnostic amphiboles and plagioclase, and because they have a relatively consistent, calcium-rich composition that ensures plagioclase can equilibrate with other calcium-bearing phases. Figure 2 illustrates the major-oxide compositional similarities and differences of the map units analyzed.

R.J. Newberry analyzed plagioclase and hornblende compositions by energy-dispersive spectroscopy-electron probe microanalysis (EDS-EPMA) using the JEOL JXA-8530 Field Emission Electron Probe Microanalyzer at the University of Alaska Fairbanks Advanced Instrumentation Laboratory (UAF AIL). Analytical beam conditions were 15 $\mathrm{keV}$ and current of $45 \mathrm{nA}$. Energy dispersive spectroscopy (EDS) was undertaken using the Thermo 7 SDD-EDS System and the analyses were reported in the Thermo Scientific ${ }^{\text {тM }}$ NORAN $^{\text {тM }}$ System 7 X-Ray Microanalysis System (NSS) software. The system was calibrated using well-characterized

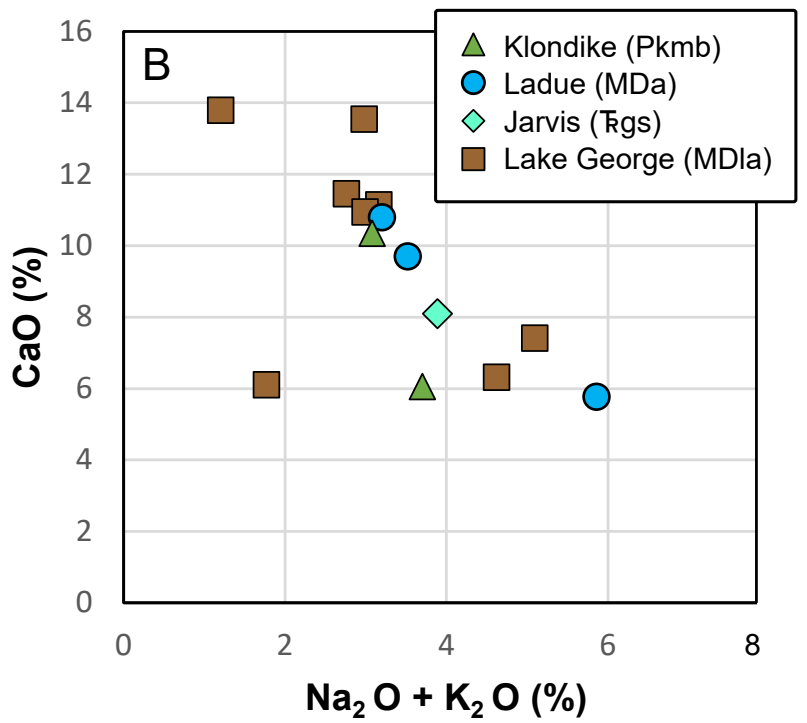

Figure 2. Bivariate scatterplots illustrating the major oxide composition of the metamafic samples analyzed by microprobe. A. $\mathrm{CaO}$ vs $\mathrm{SiO}_{2}$. B. CaO vs. $\mathrm{Na}_{2} \mathrm{O}+\mathrm{K}_{2} \mathrm{O}$. Data from Wypych and others (2019). 
natural-mineral standards as both analytical standards and analytical blanks. Count times were 60 seconds. Analyses are available in the digital data associated with this report.

\section{RESULTS}

\section{Plagioclase Compositions}

Most metamafic samples exhibit a broad range of plagioclase compositions. This unequilibrated assemblage reflects partial retrograde metamorphism (fig. 3). We interpret the high end of the percent-anorthite $(\mathrm{An})$ range to reflect remnants of peak metamorphic conditions. This offers an empirical basis for discriminating between the major metamorphic terranes in the map area based on the differences in the peak metamorphic conditions experienced by each. Plagioclase compositions above $\mathrm{An}_{30}$ are restricted to the parautochthonous Lake George amphibolite (MDla) and the Jarvis belt greenstone (kgs). Metamafic samples from the Ladue River unit contain a mix of albite and more calcic plagioclase $\left(\mathrm{An}_{1-26}\right)$, while Klondike metaba-

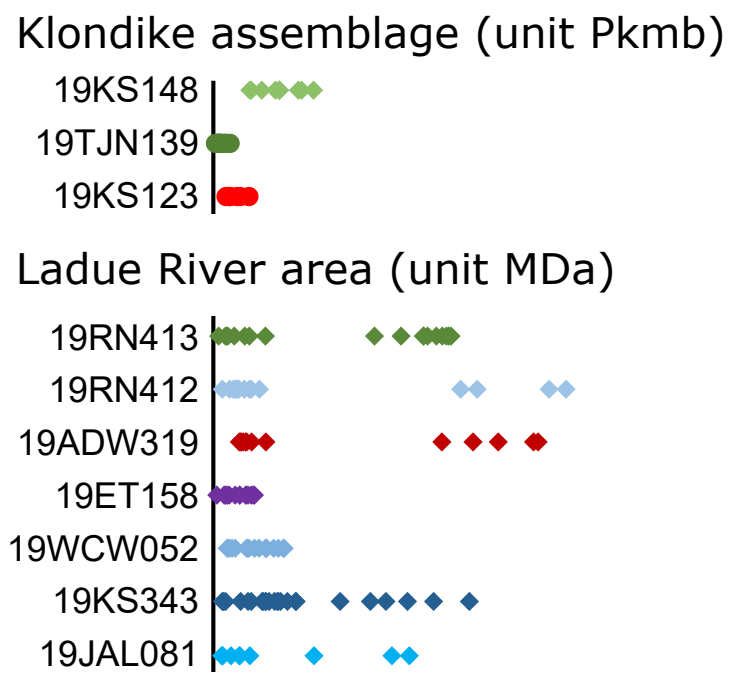

Jarvis belt (unit kgs)

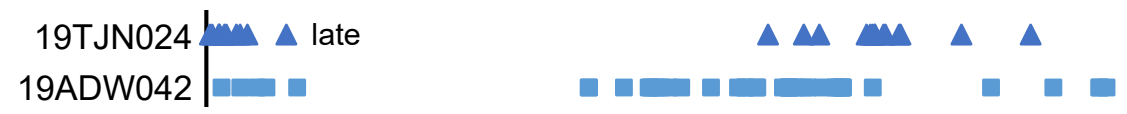

\section{Lake George assemblage (unit MDla)}

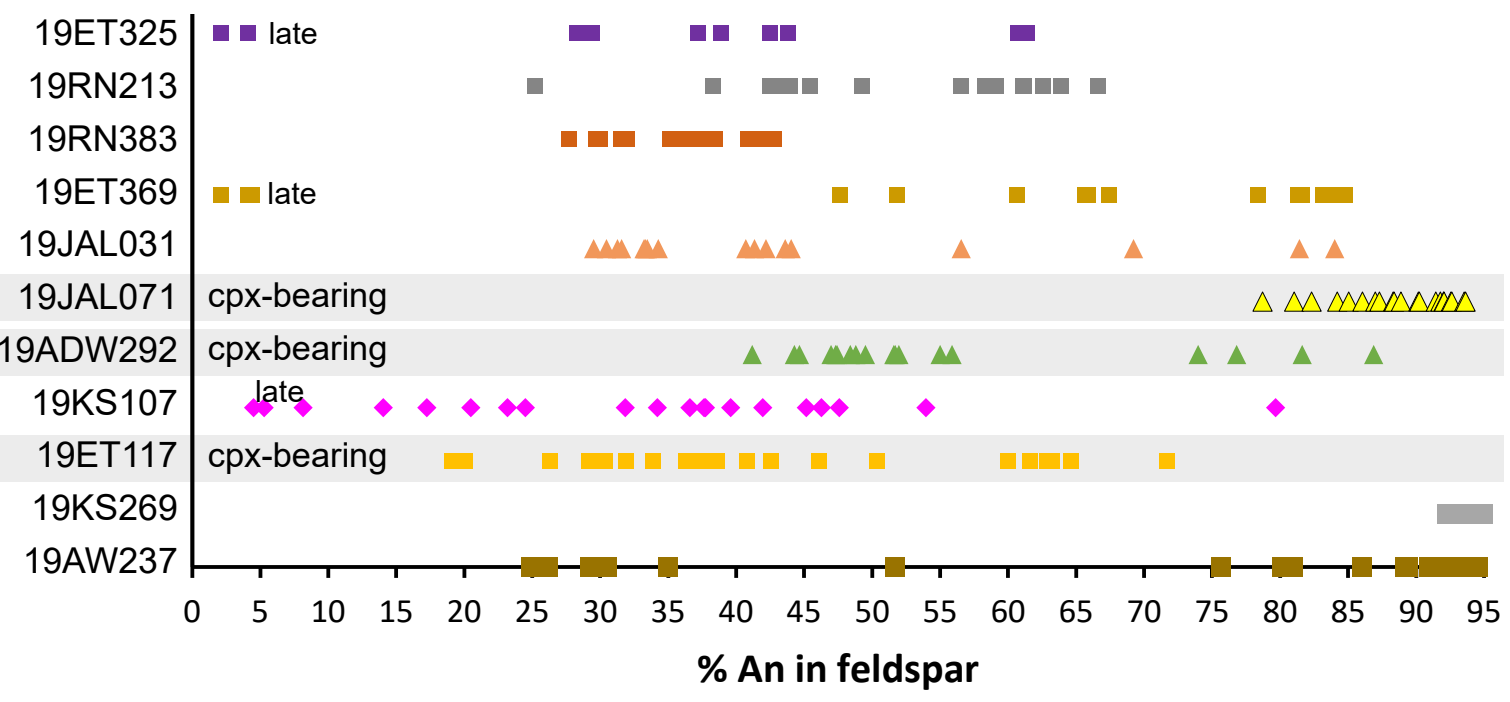

Figure 3. Plagioclase compositional data for metamafic samples (percent anorthite [An] component) based on microprobe EDS. 
site $(\mathrm{Pkmb})$ contains no plagioclase with compositions more calcic than $\mathrm{An}_{10}$ (albite).

\section{Amphibole Compositions}

The composition of "main-stage" peak-metamorphic amphibole (disregarding actinolite grain cores or retrograde overprints) in metamafic rocks also varies systematically by metamorphic terrane (fig. 4), providing a second and complementary basis for discrimination between metamorphic assemblages. Metabasite of the Klondike assemblage (Pkmb) contains only actinolite and no hornblende, whereas Ladue River unit amphibolites (MDa) contain true hornblende and/or edenite. Lake George amphibolite (MDla) and Jarvis belt greenstone ( $\mathrm{kgs}$ ) contain true hornblende, edenite, and hastingsite or parg- asite. Ladue amphibolites contain less-calcic (higher sodium $[\mathrm{Na}$ ] plus potassium $[\mathrm{K}]$ ) hornblende than those of the parautochthonous units, and their compositions are very similar to those of the allochthonous Fortymile River assemblage (fig. 4).

\section{DISCUSSION OF METAMORPHIC ASSEMBLAGES}

\section{Low-Grade Metamorphosed Ultramafic Rocks (RPum)}

Ultramafic rocks of unit $\mathrm{kP}$ zum include the low-grade metamorphic equivalents of dunite and lesser clinopyroxenite. Metamorphosed dunite (serpentinite) comprises serpentine, chlorite, dolomite, magnesite, and $\mathrm{Cr}$-magnetite; grain size is

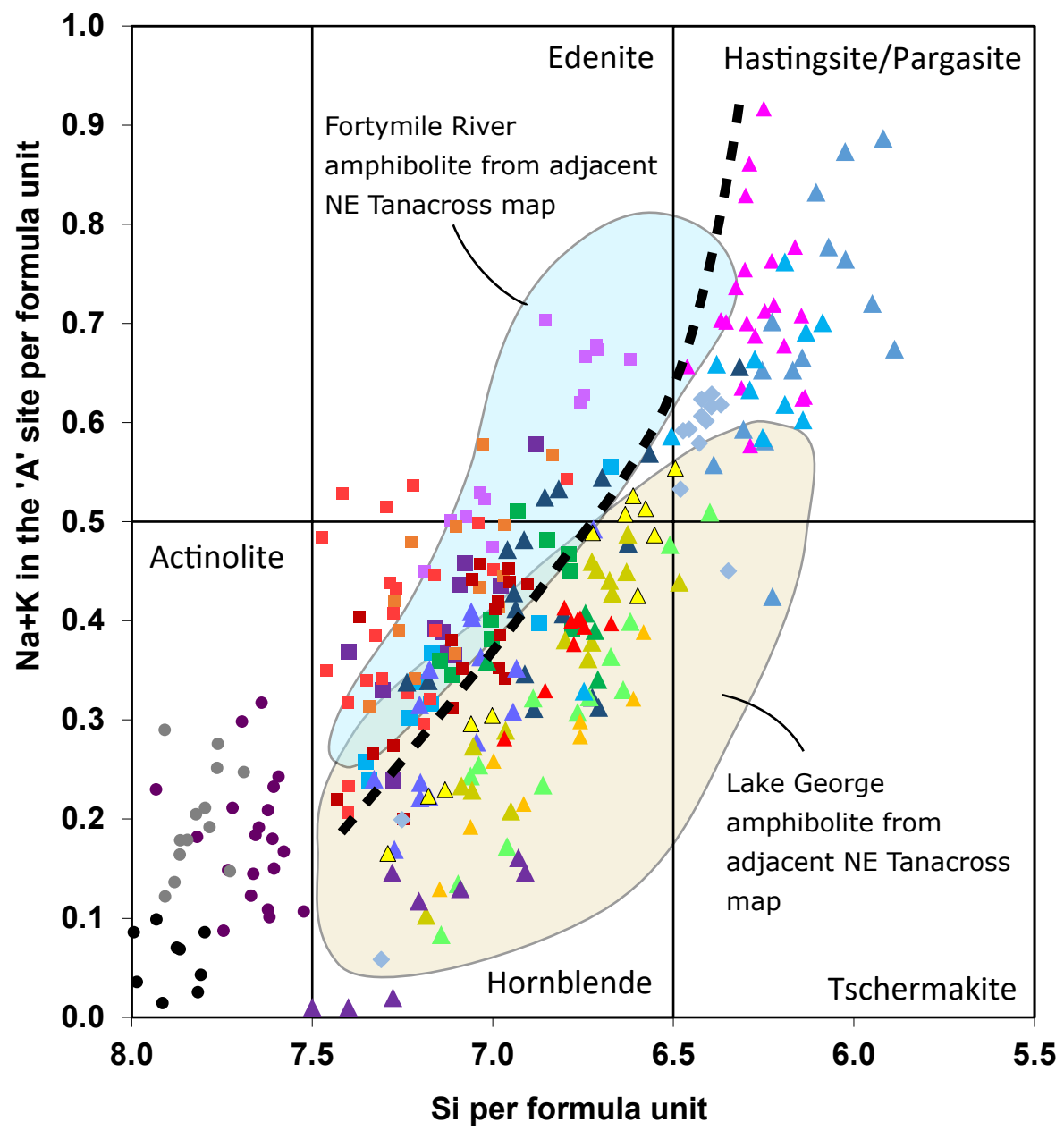

Klondike

- $19 \mathrm{KS} 148$

- 19TJN139

- 19KS123

Ladue River area

-19RN413

19RN412

19ADW319

- 19JAL081

-19KS343

- 19WCW052

-19ET158

Jarvis belt ( $\mathrm{kgs}$ )

$\triangle$ 19ADW042

$\triangle$ 19TJN024

Lake George

$\triangle 19 E T 325$

\19ET117 (cpx-bearing)

$\triangle$ 19ADW292 (cpx-bearing)

\19KS107

$\triangle$ 19JAL031

$\triangle$ 19JAL071 (cpx-bearing)

$\triangle 19 A W 237$

$\triangle 19 K S 269$

-19RN383

$\triangle 19 \mathrm{RN} 213$

$\triangle 19 E T 369$

Figure 4. Compositions of main-stage amphiboles (not including texturally late retrograde amphiboles) from metamafic samples. Fields labeled "NE Tanacross" indicate unpublished data from the Tanacross D-1 quadrangle. Data from EDS. 
very fine, 50-200 $\mu \mathrm{m}$. Metamorphosed clinopyroxenite is a tremolite-chlorite rock with lesser albite, ilmenite, and magnetite; grain size is fine, $0.2-2 \mathrm{~mm}$. Microprobe scans failed to find diagnostic indicator minerals (olivine or talc in the serpentinite; hornblende or biotite in the metaclinopyroxenite), which suggests these rocks never experienced amphibolite-facies metamorphism. We have mapped the southern locality of kPzum (near the confluence of McArthur Creek and the Ladue River) as part of the structural contact between the parautochthonous Lake George assemblage and the allochthonous rocks of the Ladue river unit, both amphibolite grade. The metaclinopyroxenite at this location must have been structurally emplaced because it never experienced amphibolite-facies metamorphism. The kPzum unit in the northeastern corner of the map separates Lake George from the overlying, allochthonous Klondike assemblage mapped in Yukon (Gordey and Ryan, 2005). The position of both ultramafic localities along the allochthon-parautochthon boundary suggests they are derived from oceanic crust of the Seventymile (Slide Mountain) terrane.

\section{Klondike Assemblage}

The Klondike assemblage includes maficto intermediate-composition greenschist ( $\mathrm{Pkmb}$ ) composed of fine-grained chlorite, actinolite, epidote, albite $\left(\mathrm{An}_{0-7}\right)$, and local quartz or biotite. Lithologies with metasedimentary or metavolcanic provenance are similarly fine-grained schists composed of quartz, white mica, chlorite, albite, epidote, and local biotite. Microprobe examination did not find relict hornblende or plagioclase. Based on these observations, we conclude that the Klondike assemblage in eastern Alaska experienced upper greenschist-facies metamorphism, but it did not experience the amphibolite-facies metamorphism that effected the other allochthonous rocks in the area.

\section{Ladue River Unit}

Amphibolite (unit MDa) is a minor constituent of the allochthonous rocks of the Ladue River unit. Prograde mineralogy includes hornblende, plagioclase $\left(\mathrm{An}_{10-25}\right)$, biotite, and phengitic muscovite; based on textural evidence, chlorite and clinozoisite may also be part of the prograde assemblage. We did not find clinopyroxene in this unit. Retrograde mineralogy includes actinolite after hornblende, albite after plagioclase, and chlorite after biotite. Metasedimentary (MPms) lithologies are siliceous and contain biotite, chloritized biotite, chlorite, and epidote-group minerals. Garnet (partially or completely replaced by chlorite) was found in several samples and seems to be more common than in the Lake George metasedimentary rocks. Combined, the mineralogy and mineral compositions (see below) indicate that the Ladue River unit experienced uppermost greenschist- to lower amphibolite-facies conditions. The metamorphic grade is lower than that experienced by the Lake George assemblage, but higher than that experienced by the Klondike assemblage in the map area.

\section{Lake George Assemblage}

Lake George assemblage amphibolites (MDla) characteristically contain hornblende, $\mathrm{An}_{25-95}$ plagioclase, and titanite; some samples contain biotite. Prograde minerals present locally include diopside and calcic almandine garnet. Microprobe examination reveals that some metamorphic hornblende retains texturally early "cores" of actinolite, and metamorphic plagioclase locally contains cores of albite. An overprinting retrograde assemblage comprises texturally late actinolite and albite, chlorite partially replacing biotite, and epidote. Lake George metasedimentary rocks (units MPIgs and Degq) are siliceous, and the contained minerals are not particularly useful as indicators of metamorphic grade. They are dominated by quartz, white mica, and biotite; rare accessory minerals include sillimanite and garnet. Based on preserved mineralogy, particularly in the amphibolites, we conclude that the Lake George assemblage rocks in the map area underwent regional peak metamorphism at upper amphibolite-facies conditions, 
followed by a partial retrograde overprint at greenschist-facies conditions.

\section{Jarvis Belt Greenschist}

Rocks of the Jarvis belt belong to parautochthonous North America (Dusel-Bacon and others, 2006). Interlayered metavolcanic rocks indicate Mississippian to Devonian depositional ages, in contrast to the Lake George assemblage where magmatism of this period occurred as plutonism, now augen orthogneiss (unit MDag). The boundary between Lake George (Macomb unit) and the Jarvis belt may be structural (Dashevsky and others, 2003) or gradational/depositional (Sicard and others, 2017). Greenstone (unit kgs) is interpreted as metamorphosed gabbroic sills. The unit is intensely retrograded to actinolite, epidote, and albite, but it nevertheless preserves remnants of "main stage" metamorphic hornblende and high-anorthite $\left(\mathrm{An}_{28-66}\right)$ plagioclase (see figs. 3 and 4). Metarhyolite (MDmr) contains fabric-forming white mica and locally, metamorphic biotite that is partially to completely chloritized. Together, this evidence suggests that the Jarvis belt rocks experienced similar, amphibolite-facies peak metamorphic conditions to the Lake George assemblage.

\section{CONCLUSIONS}

Our observations show that high-An plagioclase (greater than about $\mathrm{An}_{30}$ ) occurs only in Lake George and Jarvis belt metamafic rocks, and that Klondike assemblage metamafic rocks contain only albite and actinolite. Metamafic rocks of the Ladue River amphibolite contains plagioclase up to $\mathrm{An}_{25}$ as well as hornblende, but hornblende compo- sitions are generally distinct from those of the Lake George amphibolite. The pattern of Ladue River amphibole compositions is similar to those observed in the Fortymile River assemblage. By distinguishing allochthonous from parautochthonous terranes, our results complement the ${ }^{40} \mathrm{Ar} /{ }^{39} \mathrm{Ar}$ thermochronology approach to delineation of the metamorphic terranes of the region. They also frame additional questions for future study by highlighting similarities in peak metamorphic conditions between the Lake George assemblage and the Jarvis belt, and between the Fortymile River assemblage and the Ladue River unit. We also note a contrast in metamorphic grade between the Klondike assemblage and the underlying amphibolite-grade metamorphic rocks of the Ladue River unit; on our map we interpret this as indicating structural assembly of those units following peak metamorphism.

\section{ACKNOWLEDGMENTS}

We thank Cynthia Dusel-Bacon and Doug C. Kreiner for helpful reviews of this report. Thanks to Ken Severin and the University of Alaska Advanced Instrumentation Laboratory (UAF AIL) for use of the microprobe facilities. This project was jointly funded by the State of Alaska and the U.S. Geological Survey's Earth Mapping Resources Initiative (Earth MRI) through cooperative agreement G19AC00262. The views and conclusions contained in this document are those of the authors and should not be interpreted as representing the opinions or policies of the U.S. Geological Survey. Mention of trade names or commercial products does not constitute their endorsement by the U.S. Geological Survey. 


\section{REFERENCES}

Beranek, L.P., and Mortensen, J.K., 2011, The timing and provenance record of the Late Permian Klondike orogeny in northwestern Canada and arc-continent collision along western North America: Tectonics, v. 30, p. 1-23. https://doi. org/10.1029/2010TC002849

Dashevsky, S.S., Schaefer, C.F., and Hunter, E.N., 2003, Bedrock geologic map of the Delta mineral belt, Tok mining district, Alaska: Alaska Division of Geological \& Geophysical Surveys Professional Report 122, 122 p., 2 sheets, scale 1:63,360. https://doi.org/10.14509/2923

Dusel-Bacon, Cynthia, Lanphere, M.A., Sharp, W.D., Layer, P.W., and Hanson, V.L., 2002, Mesozoic thermal history and timing of structural events for the Yukon-Tanana Upland, east-central Alaska- ${ }^{40} \mathrm{Ar} /{ }^{39} \mathrm{Ar}$ data from metamorphic and plutonic rocks: Canadian Journal of Earth Sciences, v. 39, n. 6, p. 1,013-1,051.

Dusel-Bacon, Cynthia, Hopkins, M.J., Mortensen, J.K., Dashevsky, S.S., Bressler, J.R., and Day, W.C., 2006, Paleozoic tectonic and metallogenic evolution of the pericratonic rocks of east-central Alaska and adjacent Yukon, in Colpron, Maurice and Nelson, J.L., eds., Paleozoic evolution and metallogeny of pericratonic terranes at the ancient Pacific margin of North America, Canadian and Alaskan Cordillera: Geological Association of Canada Special Paper 45, p. 25-74.

Gordey, S.P., and Ryan, J.J., 2005, Geology, Stewart River Area (115 N, 115-O and part of 115-J), Yukon Territory: Geological Survey of Canada Open File 4970, 1 sheet, scale 1:250,000.

Hansen, V.L., and Dusel-Bacon, Cynthia, 1998, Structural and kinematic evolution of the Yukon-Tanana Upland tectonites, east-central Alaska-A record of late Paleozoic to Mesozoic crustal assembly: Geological Society of America Bulletin, v. 110, n. 2, p. 211-230.

Jones, J. V., III and Benowitz, J. A., 2020, ${ }^{40} \mathrm{Ar} /{ }^{39} \mathrm{Ar}$ isotopic data and ages for rocks from the $\mathrm{Yu}$ kon-Tanana upland of eastern Alaska and the northern Aleutian Range of south-central Alaska: U.S. Geological Survey data release, https:// doi.org/10.5066/P96762V3.

Naibert, T.J., Benowitz, J.A., Wypych, Alicja, Sicard, K.R., and Twelker, Evan, 2020, ${ }^{40} \mathrm{Ar} /{ }^{39} \mathrm{Ar}$ data from the Tanacross D-1 and parts of the D-2, C-1, and C-2 quadrangles, Alaska: Alaska Division of Geological \& Geophysical Surveys Raw Data File 2020-12, 35 p. https://doi. org/10.14509/30466

Pavlis, T.L., Sisson, V.B., Foster, H.L., Nokleberg, W.J., and Plafker, George, 1993, Mid-Cretaceous extensional tectonics of the Yukon-Tanana Terrane, Trans-Alaska Crustal Transect (TACT), east-central Alaska: Tectonics, v. 12, p. 103-122. https://doi.org/10.1029/92TC00860

Sicard, K.R., Naibert, T.J., Hubbard, T.D., Twelker, Evan, Wypych, Alicja, Werdon, M.B., Willingham, A.L., Gillis, R.J., Lande, L.L., and Newberry, R.J., 2017, Geologic map of the Tok River area, Tanacross A-5 and A-6 quadrangles, eastern Alaska Range, Alaska: Alaska Division of Geological \& Geophysical Surveys Preliminary Interpretive Report 2017-3, 15 p., 1 sheet, scale 1:63,360. https://doi.org/10.14509/29722

van Staal, C.R., Zagorevski, Alexandre, McClelland, W.C., Escayola, M.P., Ryan, J.J., Parsons, A.J., and Proenza, Joaquin, 2018, Age and setting of Permian Slide Mountain terrane ophiolitic ultramafic-mafic complexes in the Yukon: Implications for late Paleozoic-early Mesozoic tectonic models in the northern Canadian Cordillera: Tectonophysics, v. 744, p. 458-483. https://doi.org/10.1016/j.tecto.2018.07.008 Wypych, Alicja, Twelker, Evan, Naibert, T.J., Athey, J.E., Newberry, R.J., Lopez, J.A., Regan, S.P., Sicard, K.R., Wildland, A.D., and Wyatt, W.C., 2019, Major-oxide and trace-element geochemical data from rocks collected in 2019 for the Eastern Tanacross project, Tanacross and part of Nabesna quadrangles, Alaska: Alaska Division of Geological \& Geophysical Surveys Raw Data File 2019-8, 3 p. https://doi. org/10.14509/30267 